to open their markets reciprocally, and Article XXIII of the Peace Treaty guarantees "freedom of communications and of transit, and equitable treatment for the commerce of all members of the League."
The present drift is toward narrow nationalistic policies and the resultant wars; the situation demands the united consideration and coöperation of the world's most far-sighted and broad-minded statesmen.

\title{
Discriminatory Duties on Imports in American Bottoms
}

\author{
By Abraham Berglund \\ United States Tariff Commission
}

$\mathrm{D}^{\mathrm{rs}}$ ISCRIMINATORY duties on imports carried in American vessels have been a feature of our tariff legislation from the establishment in 1789 of a national policy governing foreign trade to the present time. During much of this period such duties have, for the most part, been rendered inoperative by reciprocal treaties with practically all the commercial countries of the world, mutually exempting from such discrimination the goods carried in the vessels of the contracting nations, or by provisions in the laws themselves excepting from their enforcement articles imported in the ships of countries levying no discriminatory rates against goods carried to their ports in American bottoms. The Merchant Marine Act recently passed by Congress and signed by the President provides for the termination of treaties or conventions which restrict the right of the United States to impose discriminatory duties in favor of imports entering this country in American vessels. The evident purpose of this enactment is to encourage trade in American bottoms as a means of protecting and enlarging our mercantile marine.

While discriminatory legislation of this character avowedly aims at the establishment and upbuilding of a national mercantile marine, its ultimate object is the development of foreign commerce. The belief that trade fol- lows the flag and that the vessels flying the flag of a country are agents in the development of its commerce is a popular and deep-seated one, and finds pretty general expression in the commercial policies of the leading countries of the world today. It is, however, in large measure, a survival of a period when the association of a national or communal shipping organization with the development of foreign trade was necessarily closer than at the present time, and when the separation of the functions of common carrier from those of purely mercantile operation had not gone so far as they have today. In the Middle Ages the "active"1 trade of such commercial cities as Venice and Genoa and of the towns of the Hanseatic League was closely connected with their shipping policies. Thus, at Venice

1 In mediaeval commerce "active" trade signified the carriage of goods to foreign lands and the establishment there of commercial agencies. It implied the control of the transportation of the articles of commerce to such countries. Where goods were carried by foreigners to one's city or country and commercial transactions carried out by foreign agencies the trade was characterized as "passive." The trade of Venice, for example, with Constantinople, Beirut, Alexandria and northwestern Europe was active-i.e. the articles of commerce were carried to and from these places in Venetian galleys and contracts made through Venetian agents at these ports or regions. The overland trade of Venice with Germany was mainly "passive," as the German brought his goods to the city and carried on his transactions at the Fondaco dei Tedeschi. 
from about 1300 to $1500 \mathrm{~A}$. D. the sailing of the Flanders galleys was strictly regulated by the Venetian senate. Separate voyages were as a rule prohibited. This regulation was practiced in the interest of safety, both as a protection from piracy and as a means of mutual help in case of accident. It was also a feature of the politics of a community whose economic basis was foreign trade. The galleys that carried the articles of commerce were as much a part of the city's trading operations as was the sale of the articles them. selves.

With the growth of the large commercial companies of the fifteenth, sixteenth and seventeenth centuries in England, France and the Netherlands, the close association of shipping and foreign trade persisted, largely because vessel operation and commerce were carried on by the same people. The merchants belonging to such organizations as the Eastland Company, the Merchant Adventurers, the Levant Company and the various East India companies, either individually, ${ }^{1}$ or through these organizations, owned the vessels that carried their goods. It was on account of this association, as well as on account of the growth of economic nationalism or mercantilism, that the Navigation Acts became such a prominent feature of the commercial policy of England in the seventeenth and eighteenth centuries. These acts,

${ }^{1}$ It should be remembered in this connection that most of these commercial concerns began as "regulated" companies, i.e., as associations of individuals who had been granted charters by their governments giving them as an association certain exclusive privileges for carrying on trade between the home country and certain foreign lands. The members of these associations, however, carried on their trading operations severally, losing or gaining as individuals. Eventually the "regulated" company evolved into a joint stock company. The English East India Company began its existence as a "regulated" company but adopted the joint stock company principle in 1612. among other things, restricted or tabooed the carriage of articles of commerce to or from England in foreign vessels. The British mercantile marine, as far as possible, was to perform this function. It must, therefore, be fostered, not only because it would obviate the necessity of paying foreigners for the transportation of English goods, but also because a large national mercantile marine meant an extensive foreign trade.

\section{English Navigation Acts}

Before discussing the provisions contained in American tariff acts discriminating against goods imported in foreign vessels a few observations should be made concerning the English Navigation Acts, as certain features of these acts have been embodied in our own legislation. The beginnings of the English Navigation Acts antedate by some centuries the development of mercantilism as a national policy. The earliest of these laws go back to 1381 and 1390. They ordained that no merchandise should be shipped out of the realm except in British ships on payment of forfeiture. These laws and their successors till about the middle of the seventeenth century remained for the most part unenforceable. The great Navigation Act of 1651, passed under Cromwell and aimed primarily at the shipping and commercial interests of the Netherlands, stands out as a landmark in British commercial history. This wellknown act provided among other things that all products " of the growth, production, or manufacture of Asia, Africa or America, or any part thereof . . . as well of the English plantations as others" should be imported into England or its territories only in British-built and Britishmanned vessels. Articles grown or made in Europe could be shipped to England only in the vessels of the pro- 
ducing country or in British ships, except silks transported overland to the northwestern coast of the continent. ${ }^{1}$

Later navigation acts added to the monopoly of shipping that of colonial commerce and markets. ${ }^{2}$ These acts with certain modifications practically continued in force down to the time of the American Revolution. The loss of her American colonies combined with a gradual change from the mercantilistic attitude toward foreign trade resulted in a freer shipping policy on the part of England, although discrimination against foreign vessels and the goods carried in such vessels continued for several decades into the nineteenth century.

American tariff legislation began while the spirit of the Navigation Acts still influenced British statesmen. While the first acts were modest rompared with more recent legislation in the duties they exacted from imported articles, discriminatory rates were imposed in the interest of goods carried in American bottoms. The ostensible purpose of these provisions was the upbuilding of the American merchant marine, which in colonial times had formed a considerable fraction of the entire British shipping. ${ }^{3}$ In the words of Chancellor Kent:

The United States have imitated the policy of England and other commercial nations

\footnotetext{
${ }^{1}$ Macpherson, Annals of Commerce, II, pp. 442-444. Lindsay, Merchant Shipping and Ancient Commerce, II, p. 183.

2 The Navigation Acts did not interfere with colonial ship-building and shipping. In fact, they rather tended to foster these industries. It was the regulations with reference to enumerated and non-enumerated commodities, to trade with the West Indies, and to the manufactures permitted in the colonies that made these acts so irritating to the settlers in the New World.

${ }^{3}$ At the time of the outbreak of the American Revolution about one-third of the British shipping engaged in foreign trade was colonial built. Bogart, Economic History of the United States, p. 95; Alan Beer, Commercial Policy of England toward the American Colonies, Chapters 4-8.
}

in conferring peculiar privileges upon American-built ships and owned by our own citizens. The object of the Registry Acts is to encourage our own trade, navigation and shipbuilding by granting peculiar or exclusive privileges of trade to the flag of the United States, and by prohibiting the communication of these immunities to the shipping and mariners of other countries. ${ }^{1}$

\section{American Thriff Acts}

The first general tariff act, passed by Congress in July, 1789, provided for a 10 per cent discount in rates below the general import duties where goods from foreign countries were

imported in vessels built in the United States, and which shall be wholly the property of a citizen or citizens thereof, or in vessels built in foreign countries, and on the sixteenth day of May last, wholly the property of a citizen or citizens of the United States, and so continuing until the time of importation. ${ }^{2}$

In addition to this discrimination the Act of $\mathbf{1 7 8 9}$ gave the maximum protection to American shipping engaged in the trade with the Orient. An import duty ranging from 6 to 20 cents per pound was imposed on tea when shipped directly from India or China in American bottoms. When transported from Europe to the United States in American vessels, the corresponding rates ranged from 8 to 26 cents per pound. The duties on tea shipped in foreign vessels ranged from 15 to 45 cents per pound. All other Oriental products carried to the United States in foreign bottoms bore a duty of $12 \frac{1}{2}$ per cent ad valorem, which was about double the rates imposed on the corresponding goods transported in American vessels. ${ }^{3}$

On account of the lack of sufficient revenue from the duties imposed by the Act of $\mathbf{1 7 8 9}$ material increases were made in the rates prescribed by the

1 Kent, Commentaries, III, p. 139.

2 Act of July 4, 1789, sec. 5 .

'Ibid., sec. 1. 
law of 1790. Similar preferential duties were prescribed on Oriental goods shipped direct to the United States in American bottoms as in the Act of 1789. A notable change in the latter law was the substitution of a 10 per cent addition to the general rates on goods "imported in ships or vessels not of the United States, except in the cases in which an additional duty is hereinbefore specially laid on any goods, wares, or merchandises, which shall be imported in such ships or vessels" 1 for a 10 per cent reduction on articles imported in American bottoms. This 10 per cent addition to the normal rates in the case of imported merchandise carried in foreign vessels was also provided for in the laws of $1792^{2}$ and $1794 .^{\circ}$

In addition to these higher duties on imports transported in foreign ships legislation was enacted imposing discriminatory tonnage taxes on the vessels themselves. In 1789 these tonnage dues were 6 cents per ton on vessels built and owned in the United States or on foreign-built vessels owned on and after May 29, 1789; 30 cents on ships thereafter constructed in the United States but partly or wholly owned by foreigners; and on all other shipping, 50 cents per ton. ${ }^{4}$ In 1804 a light-money tax of 50 cents per ton was imposed on foreign vessels, and this rate was increased to $\$ 1.50$ per ton in 1812. Like the discriminatory duties against goods shipped in foreign vessels these added tonnage and lightmoney taxes on the vessels themselves were later rendered inoperative by reciprocal treaties.

From 1794 to 1815 the addition of a 10 per cent duty to the normal rates on goods imported in foreign vessels re-

${ }^{1}$ Act of August 10, 1790, sections 1 and 2 .

${ }^{2}$ Act of May 2, 1792, sec. 5 .

${ }^{3}$ Act of June 7,1794, sec. 4.

${ }^{4}$ Aet of July 20, 1789. mained a feature of our tariff laws. Exceptions, however, were made in the case of merchandise belonging to British subjects and brought into the ports of the United States on the northern and northwestern frontiers and similar importation into the ports on the Mississippi River or its branches from "New Orleans and other parts of Louisiana and Florida." Such merchandise paid the same rates of duty whether carried in American or foreign vessels. ${ }^{1}$ After the purchase of Louisiana in 1803 goods carried in French and Spanish ships were similarly privileged in the ports of Louisiana for a period of 12 years from the ratification of the treaty ceding this territory to the United States. ${ }^{2}$

The trade relations between England and the United States during this period were strained, largely on account of the troubles growing out of the French Revolution and the rise of Napoleon. Until 1797 the trade between this country and Great Britain was not on a permanent footing but regulated by Orders in Council, and this regulation caused considerable uncertainty. Another source of irritation to Americans was the failure to admit American vessels into the British West Indies. The Jay Treaty, signed by Lord Grenville and John Jay in November, 1794, but not made effective until 1797 , was an attempt to remedy this situation. ${ }^{3}$ The commerce between Great Britain and the United States was put on a more permanent basis, American ships being allowed to carry into Great Britain such produce of their own states as was admissible in English vessels. A tonnage duty was levied against American vessels and discriminating tariff rates on goods carried on them "in or-

${ }^{1}$ Act of May 1, 1802.

${ }^{2}$ Act of February 24, 1804.

${ }^{3}$ Lindsay, Merchant Shipping and Ancient Commerce, II, p. 354 and III, pp. 60, 61. 
der to countervail any duties levied on goods imported into the United States by British ships." With reference to commerce between the United States and the British West Indies, the treaty provided only for the admission into the ports of the latter islands of American vessels not exceeding seventy tons burden. Such vessels were allowed to carry "articles of United States produce as were not generally prohibited," and, at the same time permitted to export therefrom to the United States any produce of the West Indies legally exportable thereto in British vessels. ${ }^{1}$ A curious proviso was appended to this clause:

That this liberty only extends to a direct intercourse between the British West Indies and the ports of the United States and the United States engage to prohibit the carriage of molasses, sugar, coffee, cocoa, or cotton $^{2}$ in American vessels, either from his Majesty's dominions or from the United States to any other part of the world.

This treaty though ratified by Congress caused great dissatisfaction among the American people, partly because of its failure to provide against certain abuses which eventually led to the War of 1812 and partly on account of some of the provisions above stated giving undue advantage to English merchants and shipping companies. The arrangement with regard to the opening of the trade with the West Indies appears to have fallen to the ground. A later treaty in 1806 contained a recital that the high contracting parties had been unable to arrange the terms on which

\footnotetext{
${ }^{1}$ Lindsay, Merchant Shipping and Ancient Commerce, III, pp. 60, 61.

${ }^{2}$ The provision with regard to cotton in this treaty has excited much comment. It should be remembered, however, that cotton did not become an important article of American export until some years after the invention of the cotton gin in 1793. The great importance of American cotton was not realized until several years after the signing of this treaty.
}

the commerce between the United States and the West Indies was to be carried on.

In 1815 a new step was taken in shipping legislation by establishing reciprocal liberty of commerce. That year a law was passed repealing

so much of the several acts imposing duties on the tonnage of ships and vessels, and on goods, wares and merchandise imported into the United States, as impose a discriminating duty of tonnage between foreign vessels and vessels of the United States, and between goods imported into the United States in foreign vessels and vessels of the United States.

This repeal was to take effect whenever the President of the United States shall be satisfied that the discriminatory or countervailing duties of such foreign nation, so far as they operate to the disadvantage of the United States, have been abolished.'

In accordance with this act a treaty with England a few months later provided that no discriminatory tonnage taxes or import duties should be levied against the vessels of either country or their cargoes. ${ }^{2}$

The treaty with England abolished differential duties and tonnage taxes only in the case of the direct trade between the contracting parties. Where the vessels of either nation touched the ports of a third country and took on additional cargoes they were again subject to discriminatory rates. The ports of the British West Indies too remained practically closed to American vessels. For the next fifteen years various negotiations were entered into for the purpose of allowing goods to be carried between this country and the British West Indian and South American possessions in British and American vessels on the same terms. The conduct of these negotiations was accompanied with many irritating inci-

\footnotetext{
${ }^{1}$ Act of March 3, 1815. S. L. III, chap. lxxvii.

${ }^{2}$ Lindsay, III, pp. 60, 61 .
} 
dents and in 1823 Congress authorized the President to prohibit all trade and intercourse with the British possessions in America. ${ }^{1}$ In May, 1830, Congress passed a law giving the President the power to open the ports of the United States to British vessels on the same terms as American vessels whenever he should have "evidence that Great Britain would open the ports of her colonial possessions in the West Indies, South America and the Bermudas for a limited or indefinite time to United States ships at the same rates of impost and tonnage and with the same cargoes as British vessels," and allow exports from these possessions to any other country in American vessels on the same terms. ${ }^{2}$ In November of the same year a British Order in Council was issued repealing various earlier orders restricting the rights of American vessels and authorizing them to carry goods to and from the British possessions mentioned on the same terms as English vessels. One result of the opening of the British West Indies to American vessels was a great increase in trade. Imports from these islands in 1830 amounted to only $\$ 1,901 .^{3}$ In 1840 they had increased to $\$ 2,965,585$.

While the matter of discriminatory duties and tonnage taxes in the British West India trade was being settled, conditions were shaping themselves for a more liberal policy with reference to foreign shipping generally. The law of 1815 and subsequent acts up to 1828 applied only to the direct trade between this and the foreign countries with which we had reciprocal treaties. In

${ }^{1}$ Act of March 1, 1823. Proclamation prohibiting this trade was issued March 17, 1827.

${ }^{2}$ Act of May 29, 1830.

3 This limited trade, of course, was due to the restrictions put upon it in the United States on account of the failure of Great Britain to allow merchandise to be exported from the islands in American vessels on the same terms as British vessels. accordance with the spirit of the English Navigation Acts, which limited the European trade to British vessels or the vessels of the country producing the goods and wares which formed their cargoes, foreign ships carrying goods to the United States which were not of the production of the country whose flags they flew were subject to discriminatory imposts and tonnage dues. In 1828 , in conformity with an act of Congress, the practice of applying these reciprocity treaties and exemptions only to vessels engaged in the direct trade was definitely abandoned.

After the passage of the laws of 1815 , 1828 and 1830 treaties were negotiated with practically all the maritime countries of the world exempting from discriminatory duties the cargoes transported in the vessels of the several contracting nations. As a consequence the clauses of later tariff acts providing for a 10 per cent increase over the general rates of duty where the imported product enters the United States in foreign vessels have been of no practical importance. For over three-quarters of a century goods produced in foreign countries have for the most part been subject to the same customs duties, regardless of whether they have come in vessels of American or foreign registry.

Various reasons have been assigned for the abandonment of this form of protection to American shipping. It has been suggested that Congress evidently believed that the American merchant marine had reached a point where it no longer needed this protection. It has also been urged that foreign commerce, while continuing to increase, was becoming relatively less important than the domestic trade. With the diversion of much American capital to works of internal improvement and domestic manufacture it has been claimed that public interest in 
the merchant marine declined, and a gradual modification of the tariff policy in the interest of home industries ensued. ${ }^{1}$

While these reasons were factors in the situation they were not in the judgment of the writer the most important. It is true that in the early decades of the nineteenth century there was great confidence in the ability of the American mercantile marine to meet foreign competition without any protectiona confidence which remained strong until after the Civil War. An increasing amount of American capital was also going into other industrial channels. There was furthermore some movement after 1815 in the direction of protection to home manufactures. The confidence in the competitive strength of American shipping, however, went back to colonial times and was not, therefore, the growth of the second and third decades of the nineteenth century. While capital was indeed being invested in other industries a sufficient amount went into the maintenance and upbuilding of the national mercantile marine to give the United States about one-third of the world's vessel tonnage just before the outbreak of the Civil War. The change, too, in tariff policy after 1815 in the direction of protection reached a climax when the Act of 1828 was passed, after which the general movement until 1861 was in the direction of reduced duties and freer trade.

\section{Growth of the American Mer- Cantile Marine}

The growth and maintenance of the American mercantile marine were partly dependent upon a policy of equitable treatment in foreign ports. The discriminatory duties and tonnage

\footnotetext{
1 These reasons are mentioned in Johnson and Huebner, Principles of Ocean Transportation, p. 413.
}

taxes levied against American shipping by England, both in Great Britain and in the British West Indies, were keenly felt and resented in this country. It was the realization of the seriousness of such a handicap that led to the adoption of the policy of reciprocal liberty in the United States.

The policy of exempting from additional tariff duties the cargoes of vessels belonging to such foreign countries as granted corresponding favors to the goods carried in American bottoms continued till the passage of the Merchant Marine Act of 1920. During the intervening period following the adoption of this policy of reciprocal liberty, tariff laws generally contained a section or paragraph imposing an additional 10 per cent duty on all goods imported in vessels of foreign registry, but with the proviso that the additional duty should not apply to "goods, wares and merchandise, imported in ships or vessels not of the United States, entitled by treaty, or by any act or acts of Congress, to be entered in the ports of the United States, on payment of the same duties as are paid on goods, wares and merchandise imported in ships or vessels of the United States."'1 A further discriminatory rate of 10 per cent was sometimes imposed on imported merchandise coming from any port or place east of the Cape of Good Hope in foreign vessels, subject, however, to the usual exemptions by treaty or Congressional enactment. ${ }^{2}$

In addition to the discriminatory provisions mentioned there is still in recent tariff laws the enactment, that no goods, wares, or merchandise, unless in cases provided for by treaty, shall be imported into the United States from

${ }^{1}$ Act of April 27, 1816 and following tariff acts including that of 1913.

${ }^{2}$ Act of Aug. 30, 1842, sec. 11; Aug. 5, 1861, sec. 3; June 30, 1864, sec. 17. 
any port or place, except in vessels of the United States, or in such foreign vessels as truly and wholly belong to the citizens or subjects of that country of which the goods are the growth, production or manufacture, or from which such goods, wares, or merchandise can only be or most usually are, first shipped for transportation. ${ }^{1}$

The penalty for violation of this provision is forfeiture of vessel, cargo, tackle, etc. 'This law like the preceding is subject to the usual exemptions by treaty or special acts of Congress. The provision is of no practical importance, but is interesting as a survival of the spirit of the Navigation Acts.

The American merchant marine continued to be an important factor in the world trade up to the time of the Civil War. Certain contemporaneous changes in the building and operation of ocean vessels ${ }^{2}$ were slowly undermining the strength of American shipping, at least that part of it engaged in international trade. From the close of the Civil War till after the outbreak of the World War the merchant marine of the United States was a relatively insignificant influence in international commerce. Before 1914, however, there was a marked revival of interest in this country in shipping, with many proposals for encouraging its development. In the Tariff Act of 1913 there was in addition to the usual provision for a 10 per cent increase of duties over normal rates on articles imported in foreign vessels another clause granting a discount of 5 per cent "on such goods, wares and merchandise as shall be imported in vessels admitted to registration under the laws of the United

Acts of Oct. 1, 1890, sec. 18; Aug. 27, 1894, sec. 15; July 24, 1897, sec. 23; Aug. 5, 1909, sec. 16 ; Oct. 3,1913 , sec. $4 \mathrm{~J}$, subsection 2 .

2 'These changes were concerned with the substitution of iron and later steel for wood in the construction of ships and steamships for sailing vessels.
States" accompanied with the usual proviso in regard to treaties. ${ }^{1}$ While no discounts under this clause have been granted to imported articles carried in American vessels, ${ }^{2}$ the insertion of this subsection in the Act of 1913 is some indication of the rising influence of shipping interests.

The World War gave a great impetus to the growth of the American mercantile marine. From June, 1914 to June, 1919, according to Lloyd's Register of Shipping, it increased from about $5,500,000$ gross tons to 13,091 ,773 gross tons, ${ }^{3}$ and in June, 1920, amounted to $16,049,289$ gross tons. Most of this great development has taken place in that part of our shipping engaged in foreign commerce. The movement to conserve this growth and maintain on the high seas the position attained during the war resulted in the passage in 1920 of the Merchant Marine Act. Among its several provisions for the development and maintenance of American shipping is the following:

Sec. 34. That in the judgment of Congress, articles or provisions in treaties or

1 Act of Oct. 3,1913, sec. 4J, subsections 1 and 7 .

2 The question arose whether or not a 5 per cent discount should not be allowable on all goods carried in American vessels and vessels of foreign countries with which we had reciprocal treaties. It was held by the Supreme Court of the United States that the provision was operative only when goods came in vessels of countries with which the United States had no agreement. 243 U.S. 97 of 1917.

${ }^{3}$ Lloyd's Register of Shipping, 1914-1915, II, pp. 960, 961 and 1919-1920, II, p. 960. The figures for 1914 in Lloyd are $4,330,078$ gross tons steam, and 1,038,116 net tons sail. Adding the gross tons of steam vessels and the estimated gross tons for sailing ships the total would be approximately $5,500,000$ gross tons. This figure does not include a considerable tonnage of river craft, barges, motor boats and certain wooden vessels on the Great Lakes. These are added in the published figures of the reports of the Commissioner of Navigation, whose total for 1914 is $7,928,688$ gross tons instead of $5,500,000$. 
conventions to which the United States is a party, which restrict the right of the United States to impose discriminating customs duties on imports entering the United States in foreign vessels and in vessels of the United States, and which also restrict the right of the United States to impose discriminatory tonnage dues on foreign vessels and on vessels of the United States entering the United States should be terminated, and the President is hereby authorized and directed within ninety days after that act becomes law to give notice to the several Governments, respectively, parties to such treaties or conventions, that so much thereof as impose any restriction on the United States will terminate on the expiration of such periods as may be required for the giving of such notice by the provisions of such treaties or conventions.

This act, and especially the provision quoted, has excited a great deal of attention abroad, and the announcement of its passage has been followed by threats of retaliation. It is reported that no action has yet (December, 1920) been taken with a view to terminating existing treaties, but such action is anticipated and provided for in the law.

The expediency of reverting to this discriminatory practice may be briefly considered with reference, first, to the protection of the mercantile marine of the United States so rapidly developed during the war, and second, to the advisability of resorting to such means in order to attain the end sought.

1. The need of a national mercantile marine is not based upon the same grounds as formerly, and barring the importance of such a fleet in furnishing auxiliary cruisers in time of war, is not so urgent. ${ }^{1}$ The functions of merchant

\footnotetext{
${ }^{1}$ See a fine statement of this side in Referendum No. 29 on Report of Committee on Ocean Transportation Regarding Government-Owned Merchant Ships-Arguments in the Negative, Chamber of Commerce of United States of America.
}

and ocean carrier have become more differentiated than formerly. While large manufacturing and trading companies often own the vessels which transport their goods, this combination of functions is now largely confined to companies producing bulky commodities in large quantities, which find that by owning and operating their own vessels they avoid much loss of time and uncertainties with reference to proper space and service. Neither is the association of government and carrying trade so close as formerly. The commodities shipped by the merchants of one country are now often carried safely and expeditiously in vessels flying the flag of another.

The government of the world, however, is carried on by nations, and when foreign commerce is discussed people think of it in terms of national units. A large merchant fleet flying the flag of a country on the high seas and in foreign ports does exert some psychological influence. It advertises the country.

With these considerations in view we see the United States at the close of a world crisis possessed of a greatly enlarged merchant marine. Has this transformation been in accord with the economic conditions of the country or is it merely an artificial, and therefore temporary, development, due to a great world emergency? This question has been discussed elsewhere by the writer ${ }^{1}$ and just a few observations will be made here.

The decline of American shipping after 1860 is connected with the introduction of iron and later steel vessels and the substitution of steam for sailing tonnage. It was due mainly to the higher cost in this country of iron, steel and coal. Until the late nineties steel plate and structural steel were

${ }^{1}$ The American Economic Review, June, 1920, “The War and the World's Mercantile Marine." 
higher in price here than in England. For a long time bunker coal at our Atlantic seaboard was also more expensive. Added to these handicaps were greater labor costs both in building and in operating vessels. Before the war broke out these conditions had changed. Steel and coal had become appreciably cheaper, and while labor cost remained high it formed a smaller fraction of the total cost of operation than in earlier years. ${ }^{1}$ 'The recent change from the use of coal to that of oil also favors the operation of vessels by American concerns. ${ }^{2}$

On the other hand for two generations the United States has been a country whose principal industrial interests have been devoted to land pursuits. As a result the country has a very limited sea-faring population and now lacks the experience which certain European countries have in the conduct of shipping operations on an international scale. We have, therefore, a hiatus between economic position and experience; and it is to bridge this gap that some protection may be temporarily necessary.

2. Is, however, a return to discriminatory import duties the best means of safeguarding our newly acquired position as the second maritime nation of the world? A very common experience with industrial advances, as with political and social reforms, is the occasional reversion to practices which have been outgrown or found out of

${ }^{1}$ It is difficult to give any definite percentage of the total cost of operation which is properly attributable to labor engaged directly in the sail ing of a vessel. It is, however, smaller than commonly supposed. Ten per cent is a large proportion for coal-burning freight vessels.

2 There is, of course, involved in the statement the question of the exhaustion of oil resources and the possible monopolization of oil in other parts of the world by foreign concerns. For some time the British monopolization of the Mesopotamian and Persian fields was reported, but this has since been denied. harmony with more highly developed social conditions. Reciprocal freedom of trade was attained only after much struggle with a growing realization that the practice of discriminatory rates invariably led to retaliation. Already measures have been taken by Japan to retaliate if certain provisions in the Merchant Marine Act, including the one quoted above, are carried out, ${ }^{1}$ and hints of similar reprisals are made in Europe.

Another fact to be considered in this connection is the general character of our export trade and the probable effect of foreign retaliatory measures. In the calendar year 1919 over 33 per cent of our exports consisted of manufactures ready for consumption; about 12 per cent, of manufactures for further use in manufacturing; and over 25 per cent, of foodstuffs partly or wholly manufactured. Only about 20 per cent consisted of crude materials for use in manufactures-the bulk of it being raw cotton. ${ }^{2}$ In other words about 70 per cent of our exports are manufactured articles, in many lines of which retaliatory measures on the part of foreign governments are likely to undermine the American competitive position. Furthermore, coming at a period when the foreign exchange situation is likely to favor the foreign producer, such a step appears illadvised.

There is, however, a justifiable resort to discriminatory legislation of the character considered above in cases where American vessels are practically excluded from trade by foreign conference lines. To illustrate: The United States imports a large amount of Egyptian cotton. All of this cotton comes to this country in foreign vessels. There are American ships operating in

\footnotetext{
${ }^{1}$ The Economic Review (England), Nov. 19, 1920 , p. 29.

${ }^{2}$ The Statistical Abstract, 1919.
} 
the eastern Mediterranean, but thus far practically every American vessel leaving Alexandria goes away empty. This loss of freight is ascribed to a powerful British combination which excludes the ships of this country from any participation in its conferences or trade. Similar exclusive combinations exist in other parts of the world. ${ }^{1}$ The imposition of discriminatory customs duties against the products carried in the vessels of countries whose shipping organizations or conferences clearly exclude American companies from any participation in trade would be justifiable and probably feasible. Treaties granting reciprocal liberties to the shipping of the contracting parties might be so framed as to provide some protection against discriminatory practices on the part of private combinations. ${ }^{2}$

While the resort to discriminatory tariff rates as a regular policy is a reversion to an earlier practice that the commercial world has outgrown it does not follow that some aid or pro-

${ }^{1}$ Hearings before Committee on Commerce, United States Senate, 66th Congress, 1st Session, pp. 299, 300; 'Testimony of J. H. Rosseter of Emergency Fleet Corporation. The Sunday Star, Washington, D. C., January 2, 1921.

2 It is difficult to suggest anything definite here as conditions vary greatly. In many parts of the world American vessels participate in trade on the same terms as vessels of other countries. The sudden emergence of the United States as a maritime power has excited some concern on the part of other countries and some large shipping combinations are apparently attempting to "swat infant shipping industries." tection should not be rendered to the new shipping. Many suggestions have been made, among which may be cited the establishment of coaling stations abroad along important trade routes, ${ }^{1}$ assistance to shipping companies in securing experienced agencies in other countries to obtain cargoes, ${ }^{2}$ the creation of free ports in Virgin Islands, Porto Rico, Panama and Philippines, ${ }^{3}$ temporary subsidies to lines operating between the United States and regions whose future growth promises to pay for the outlay, ${ }^{4}$ and the sale of government-owned ships at prices low enough to induce purchasers to invest and the absorption by the government of the difference between such prices and the war cost as a war loss. ${ }^{5}$ A noteworthy fact in connection with suggested aids is the almost entire absence of any demand for general ship subsidies.

It is not the purpose of this article to discuss any of these suggestions or others that have been urged. Some of these proposals will, in the judgment of the writer, mean more for the upbuilding of the American merchant marine, if properly carried out, than discriminatory tariff rates against çommodities imported in foreign vessels, and will not cause the irritation which discriminatory legislation is bound to incur.

${ }^{1}$ Hearings before Committee on Commerce, U. S. Senate, 66th Congress, 1st Session, pp. 425 and 426.

${ }^{2}$ Ibid., pp. 421, 422 .

${ }^{3}$ Ibid., p. 388.

4 Ibid., p. 391.

${ }^{5}$ Ibid., pp. 607-609 and 750-754. 